\title{
Ecotourism as a Tool for Sustainable Forest Management in Sri Lanka
}

\author{
Kanchana Wickramasinghe
}

Institute of Policy Studies of Sri Lanka (IPS)

100/20, Independence Avenue,

Colombo 7, Sri Lanka

Tel: (94) 11214 3100; Fax: (94) 11266 5065; E-mail: kanchana@ips.lk

\begin{abstract}
Deforestation and forest degradation have become serious environmental issues faced by Sri Lanka. Forest management system of Sri Lanka has been based on 'command and control' approach, which shows a limited involvement of local communities as stakeholders in forest management. It is vital that the society sees the economic benefits of forest conservation, in order to conservation being more meaningful and long lasting. Forest-based ecotourism, a non-consumptive, marketbased approach to forest utilization has received a foremost position, due to its prospective economic and environmental benefits. Through a comprehensive qualitative assessment, the study finds the key constraints and challenges in adopting ecotourism for sustainable forest management as, lack of awareness and understanding on the concept, inadequate coordination, non-compliance to principles and poor interpretation services. It highlights the need for establishing well-coordinated mechanism, assigning clear roles for relevant stakeholders, enhancing private sector participation and establishment of a certification program of ecotourism businesses
\end{abstract}

KEYWORDS: Ecotourism, Forest Management, Sri Lanka

\section{Introduction}

Rapid rate of deforestation and forest degradation have become critical environmental problems in Sri Lanka over the past few decades (MoE, 2003). It shows that the existing 'command and control' approach of forest management in Sri Lanka, has not been effective in ensuring sustainability of natural forests. Forest conservation is meaningful and long lasting, if the society sees the economic benefits of conserving forests. Market-based approaches of forest utilization have become more popular among the alternative approaches in the recent past. In this backdrop, being a non-consumptive means of utilization of forest resources (Wunder, 1999), ecotourism, based on natural forests receives a prominent place among alternative market-based approaches. Forest-based ecotourism is a non-land 
based model of sustainable forest management, which is built upon recreation services provided by the forests (Yong, 1995; Lindberg et al., 1997).

According to the definition presented by the International Ecotourism Society (TIES) in 1990, ecotourism means "responsible travel to natural areas that conserves the environment and improves the well-being of local people". Hence, ecotourism principles fit into sustainable principles of forest management. In the case of Sri Lanka, being blessed with splendid and diverse forests, wildlife resources as well as a rich cultural heritage has significant potential to be developed as an ecotourism destination. Prospects are high as ecotourism is one of the fastest growing segments in the global tourism industry (Tisdell, 2003) and Sri Lankan tourism industry is showing a strong revival following the end of civil war in May 2009. However at present, Sri Lanka performs far below its potential in ecotourism (Ratnayake, 2007). Little has been accomplished to address the issues at policy level in relation to developing ecotourism in Sri Lanka. Moreover, little or no research has been conducted on the subject of ecotourism as a possible tool in sustainable forest management. The present study intends to shed light on the said research gap with regard to policy level issues of forest-based ecotourism development.

The objectives of the study are, to identify main problems and issues that demand policy level interventions in developing forest-based ecotourism in Sri Lanka, to identify the existing management approaches to forest-based ecotourism, followed by a review of strengths and weaknesses of each approach to provide key policy implications and recommendations in promoting ecotourism as a sustainable tool for forest conservation in Sri Lanka.

The paper is structured as follows: Section 2 presents the theoretical ideas behind the role of ecotourism in sustainable forest management. The third section discusses the potential in the forestry sector and prospects from the tourism sector for the development of ecotourism in Sri Lanka. The section 4 deals with the data collection methodology. Current situation of forest-based ecotourism is assessed in the fifth section. Section 6 identifies the problems and issues in developing forestbased ecotourism. The seventh section provides key policy implications and recommendations for development of ecotourism as a sustainable tool for forest management.

\section{Role of Ecotourism in Sustainable Forest Management}

Ecotourism is widely recognized as a means to derive economic benefits from natural forest resources. From economic point of view, the total economic value of forest resources may comprise of direct use values (either extractive or non extractive), indirect use values (ecosystem services), option values (willingness to pay for conservation) and non-use values (existence value). Ecotourism falls under the category of non-extractive, direct use value. Among different types of tourism, ecotourism is often viewed as a subset of nature tourism. Conceptually, ecotourism is composed of several key features, which make it distinctive from other forms of 
tourism, including nature tourism. As per the definition presented by the TIES in 1990, the principles of ecotourism include the following:

- Minimize impact on nature and culture

- Build environmental and cultural awareness and respect

- Provide positive experiences for both visitors and hosts

- Provide direct financial benefits for conservation

- Provide financial benefits and empowerment for local people

- Raise sensitivity to host countries' political, environmental, and social climate

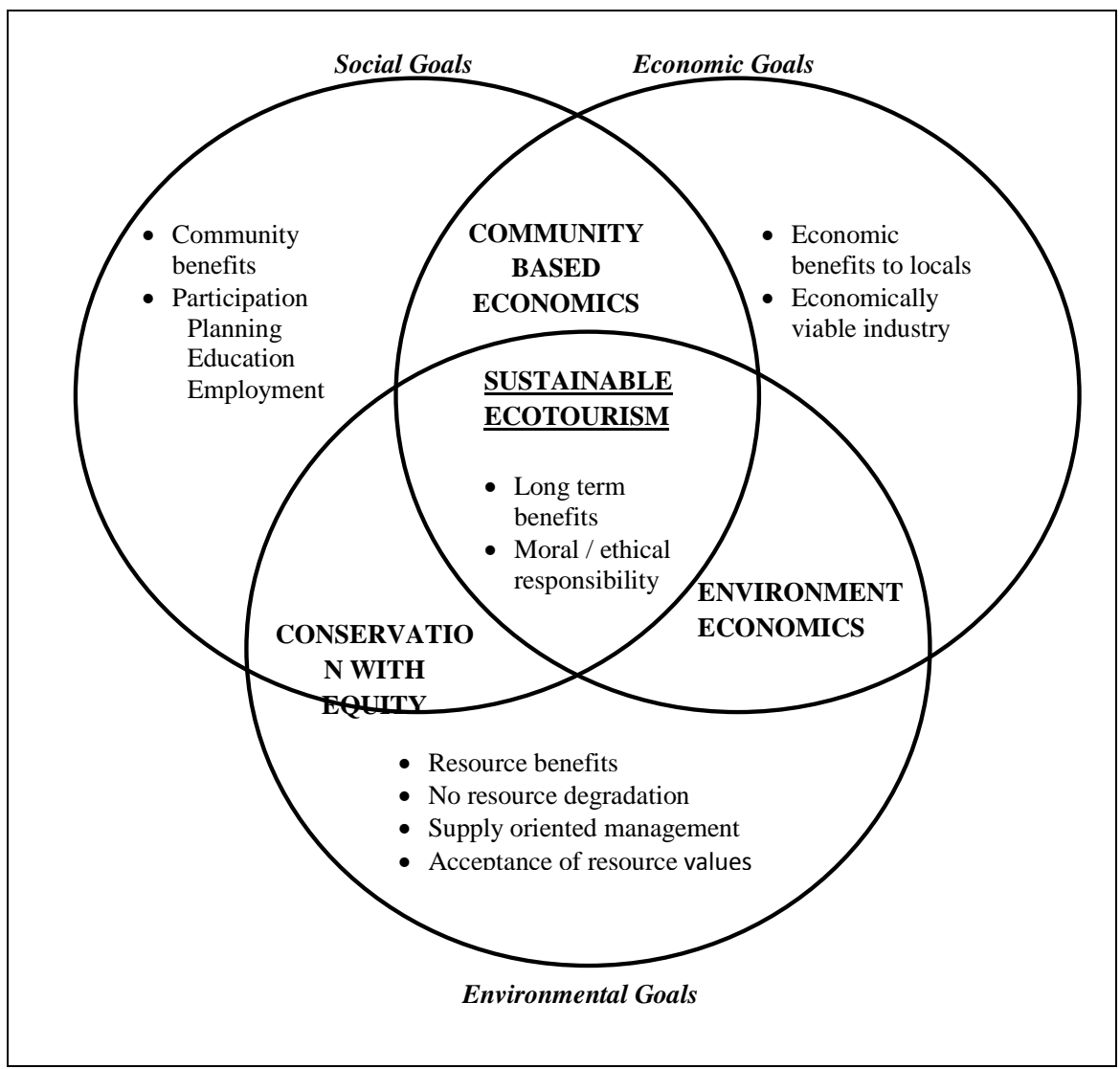

Source: Wight (1993)

Figure 1: Sustainable Ecotourism Values and Principles Model

Accordingly, ecotourism aims to extend positive impacts through a special focus on conservation, providing benefits to host communities and education to visitors. Thus in sustainable terms, ecotourism goes beyond other forms of tourism. Ecotourism lies in the sustainable development framework, since it aims to achieve social and environmental goals in addition to economic goals. Implementation of sustainable principles of is very crucial for the success of any ecotourism business. 


\section{Potential and Prospects for Forest-based Ecotourism in Sri Lanka}

\section{Forestry Sector: Potential}

Sri Lanka possesses an enormous diversity in its forest resources. The forests are rich in species diversity with a high degree of endemism and genetic diversity. Thus, from the point of view of resource base, country carries a unique natural advantage for forest-based ecotourism. Around 98 per cent of the natural forests of Sri Lanka are owned and managed by the state. The FD and the DWLC, which come under the Ministry of Environment (MENR), are the two state agencies responsible for managing natural forests in the country. The total forest land areas held by the FD is $1,421,954$ ha in the year 2007, which accounts to around 22 per cent of the total land area of the country. The total land area held by the DWLC is around 930,813 ha in the year 2008. This area constitutes of 14 per cent of the total land area of the country.

Capitalizing on the existing forest resources, Sri Lanka has been carrying out nature tourism, both in the areas held by the FD and the DWLC, for decades. Increasing number of visitations to the forest reserves and wildlife parks shows that there is a growing demand for nature tourism in Sri Lanka. A primary survey conducted by Ratnayake (2007) reveals that 65 per cent of the tourists visiting the country have expressed that Sri Lanka has a huge potential for forest-based tourism. The reputation in nature tourism can be used as a basis in developing and marketing Sri Lanka as an ecotourism destination in the future.

The forest management system of Sri Lanka presently is looking for avenues of participatory approaches of forest management. At present forests are managed through a command and control approach with limited community participation. The FD implemented a community forestry pilot project from 2003 to 2008 with donor funds in five districts of Dry and Intermediate zones of the country, where forest degradation had been a severe issue. Based on the lessons learned through the pilot project, it is expected to replicate community forestry in other suitable forest areas. It is an encouraging sign that forest-based ecotourism has been identified as one of the approaches in promoting conservation and benefiting communities in some pilot sites, such as in Ranpathwala in Ahatuwewa Divisional Secretariat Division of Kurunegala district. Thus, prospects exist that ecotourism could be acknowledged as a tool for conservation and an integrated part in the forest management system of the country.

The forestry sector of Sri Lanka is largely dependent on external funding sources. At present, the FD's budget for protected area management is funded from bilateral and multilateral aid, which in the long term cannot be assured to continue. The forestry sector lacks necessary funds to carry out its conservation activities at the ground level. Ecotourism could be a practical tool to make contributions for forest conservation, through appropriate partnerships between the state resource managing 
agencies, private sector and communities. Accordingly, forest-based ecotourism has the ability to contributing to efficient management of forest resources in Sri Lanka.

\section{Tourism Sector: Prospects}

The tourism industry in Sri Lanka has begun to record a strong recovery - with a substantial increase in arrivals in 2010 - following the end of the conflict in May 2009. Arrivals increased by 46 per cent in 2010 when compared with that of 2009 while earnings rose by 76 per cent from US\$ 326 million in 2009 to US\$ 576 million in 2010 (SLTDA, 2010). In addition, with the peaceful environment created post-war, it is expected that tourist arrivals will show a notable increase in the coming years. The war torn Northern and Eastern provinces of the country have an enormous potential for tourism, which have been so far left out due to security problems. If properly planned and implemented in a sustainable manner, the provinces will contribute significantly to the national tourism earnings of the country. The developments will pave the road for the progress of small-scale tourism activities too, including ecotourism. The Tourism Development Strategy 2011 - 2016 identifies the need for diversifying tourism products with special emphasis on ecotourism. This would provide ample opportunities for the development of ecotourism sector in Sri Lanka.

Besides, Western European tourists contribute to a notable share in the total foreign tourist arrivals (SLTDA, 2011). The share of tourist arrivals from Western Europe has been increasing by 23 per cent in 2011, when compared with 2010. Hamele (2004) finds that 20 to 30 per cent of travelers are aware of the needs and values of sustainable tourism and nearly 10 to 20 per cent of the travelers are looking for 'green' options. Thus, future developments in sustainable tourism, including forestbased ecotourism in Sri Lanka would be able to attract more nature-concerned tourists from this region of the world, if Sri Lanka is rightly positioned as an ecotourism destination.

Additionally Sri Lanka's initiative on 'greening' tourism, in response to emerging concerns of climate change, would create a highly conducive environment for ecotourism. The main goal of the initiative is to make Sri Lanka a carbon neutral destination by the year 2018. Under this initiative, with regard to the forestry sector, efforts would be made to stop deforestation, ensure reforestation, to encourage the use of alternative energy sources, to mitigate pollution at their sources through local and regional efforts and thereby to create an "Earth Lung Community". The initiative would undeniably present ample opportunities as well as spillover effects for the development of forest-based ecotourism.

\section{Data Collection}

The study is primarily based on the case study approach to analyze present status and issues of forest-based ecotourism in Sri Lanka. Focus Group Discussions (FGD) were conducted in selected locations to gather required information for case study development. The focus groups included individuals who are involved in 
ecotourism in particular locations, members in community-based ecotourism societies, village level leaders, beneficiaries etc. The selection of forest-based ecotourism sites is based on the type of management approach adopted. Accordingly, FGDs were conducted in:

a. Walathwewa in Kurunegala district - Ranpathwila Ecotourism site (represents the community-based approach of forest-based ecotourism)

b. Ilukkumbura in Matale district (represents a case where a resource managing agency, the Forest Department (FD) initiated ecotourism project)

In addition, key informant interviews were conducted with the key persons from environment and tourism sectors in Sri Lanka, to gather their perception in relation to ecotourism development. The key informants represent government agencies, NGOs and private sector organizations involved in forest-based ecotourism or nature tourism. The case study on privately managed ecotourism businesses was developed based on the interviews conducted with private ecotourism business operators and local communities and secondary information sources.

\section{Status of Forest-based Ecotourism in Sri Lanka}

There are no official tourism statistics to show the size of the ecotourism market in Sri Lanka. An ecotourist is defined as anyone travelling with the primary motivations of viewing, enjoying, and experiencing nature in a relatively undisturbed natural area and undertaking at least one ecotourism-related activity during his/her trip (Tao et al., 2004). Similar to the situation with regard to global tourism statistics, official tourism statistics in Sri Lanka also have not identified ecotourists as a separate tourist category. Since ecotourism is not yet properly developed as a market in Sri Lanka, it is difficult to differentiate ecotourists from other types of tourists (Ratnayake, 2007). However, through a primary survey, Ratnayake (2007) estimates that around 2.7 per cent of international tourists visiting Sri Lanka are ecotourists. The same survey reveals that 6.2 per cent of the international tourists have treated ecotourism as an additional activity.

\section{Stakeholders of Forest-based Ecotourism in Sri Lanka}

In Sri Lanka, the main state agencies involved in forest-based ecotourism include the SLTDA, the FD, the Department of Wildlife Conservation (DWLC) and the Central Environment Authority (CEA). The Sri Lanka Tourism Development Authority (SLTDA) (which was formally known as the Sri Lanka Tourist Board) is responsible for promoting tourism in Sri Lanka, conducting research and international affairs, tourism marketing and tourism product development. The FD and the DWLC are the owners and managers of forest resources in Sri Lanka. In addition the Sri Lanka Ecotourism Foundation (SLEF) and the Ecotourism Society of Sri Lanka (ESSL) are intended to serve ecotourism development in Sri Lanka, as 
non-profit organizations. The ecotourism stakeholders also include private tour operators and accommodation providers.

\section{Management Models of Forest-based Ecotourism}

Based on the approach of management and ownership of the business, three basic management models can be identified with regard to forest-based ecotourism in Sri Lanka. They include:

a. Ecotourism businesses which are initiated by the resource owning agencies, the FD for instance, and managed by communities. In most of the cases, such projects are financially assisted by external sources, via FD.

b. Community-based ecotourism projects promoted and supported by NGOs

c. Ecotourism businesses owned and managed by private entrepreneurs

The management models have their own strengths and weaknesses. The following sections look into the details of each management model, based on appropriate case studies and secondary information sources. The degree to which each model comply with ecotourism principles is also assessed based on gathered information.

\section{Community-based Ecotourism: Case of Ranpathwala Ecotourism Project}

Ranpathwala ecotourism project is based on an isolated forest patch in the Ahatuwewa Divisional Secretariat Division of Kurunegala district, namely Galgiriyakanda forest reserve, an ideal location for ecotourism. The reserve is managed by the FD. However, deforestation linked with illegal logging and forest degradation had been a severe problem, threatening the sustainability of the forest. The area was selected as one of the pilot sites by the community forestry program implemented by the FD with the support of Sri Lanka Australia Natural Resource Management Project (SLANRMP).

In the process of identifying avenues for benefiting communities through the project, community-based ecotourism had been suggested as a prospective alternative by the community itself. On the request of community members, the ecotourism project was supported by SLANRMP for initial take-off in terms of providing initial investment, training community members on ecotourism management, accounting etc. and creating links with relevant agencies including the Ministry of Tourism (MoT), the SLEF etc.

Community Benefits: The business is entirely owned and managed by the community. It is expected that 21 households will directly benefit through ecotourism. In addition, indirect benefits will be accrued to 57 households when the business reaches maturity over time. The Ranpathwila Ecotourism Foundation has signed a memorandum of understanding (MoU), with the FD for benefit sharing. Accordingly, 70 per cent of the revenue earned through entrance fees is retained for community activities. 
Contribution to Forest Conservation: As per the MoU, it is expected to contribute 30 per cent of the entrance fee revenue to the FD. While this allocation serves as a direct benefit, there can be a number of indirect benefits too. The community benefits of ecotourism can act as an incentive for them to actively engage in community forest management initiated by the SLANRMP. Ecotourism also has served as a means to show the communities the importance of keeping the forest intact and thereby to create a conservation attitude. Active community involvement in ecotourism and attitude towards conservation would serve a vital support for the FD, which has limited resources, for carrying out management activities efficiently.

Education Service to Tourists: Currently a few appointed members of the Foundation work as interpreters, of which one person is fluent in English. The interpreters provide information on the unique features of the forest reserve, culture and traditions of the village, etc to tourists. At present there are no educational materials distributed among the tourists. The project carries strengths and weaknesses stated below.

Strengths

- The villagers have being possessing a positive attitude towards ecotourism since the genesis of the project

- The villagers themselves have a good understanding on the natural environment and archaeological value of the reserve and are well-aware of the socio-cultural aspects in the area. This would serve as an asset for them in carrying out ecotourism.

- The villagers have gained required knowledge and skills through training provided by the SLANRMP and are educated on risks involved.

\section{Constraints}

- The community does not have enough confidence on the role and nature of collaboration of the FD, after the SLNRMP is withdrawn.

- Although the villagers had agreed to provide their labor inputs free of charge in constructing required facilities for ecotourism, due to their involvement in intensive agricultural activities it had been very difficult for them to allocate their time for ecotourism activities.

- Although the community possesses a favorable attitude towards ecotourism, lack of practical knowledge of undertaking such a business is identified as a constraint.

- Sometimes conflicts have arisen among the villagers in benefit sharing.

- It has been difficult for villagers to manage local visitors in certain occasions. 


\section{Ecotourism Project in Illukkumbura}

The Knuckles range, possesses a wide variation in climate and contains a high diversity in flora and fauna species, thus it is considered as an ideal spot for ecotourism in Sri Lanka, which can offer a rewarding experience for ecotourists. The FD declared a conservation zone in the Knuckles National Wild Heritage in the year 2000 with the aim of assuring sustainability of the forest. However, it has brought about substantial economic losses to the peripheral communities (Wickramasinghe et al, 2008). As a means of compensating forgone benefits, the FD, through an IUCN (World Conservation Union) funded project initiated an ecotourism project in the Ilukkumbura village, located in the periphery of the KNWH.

Community Benefits: Ilukkumbura is a remote isolated village which has not benefited from the government development programs. The ecotourism initiative was primarily aimed at creating an avenue for compensating forgone economic impacts of the conservation rules. Based on results of a primary survey, it is revealed that more than 95 per cent of households living in three peripheral villages of KNWH (Ilukkumbura, Atanwala, Pitawala) have perceived that ecotourism would serve as an important alternative income source for them (Wickramasinghe et al, 2008).

At present, around 8 individuals from the villages serve as tourist guides, on a part time basis. Few boutique owners benefit by selling food items to local tourists who come to visit the site. A few households earn an income by providing meals to tourists who stay in the FD lodge. As viewed by the villagers, there is a great potential to initiate small-scale businesses to produce souvenirs and related products, targeting the tourists. According to the MoU, 60 per cent of the ecotourism revenue earned is to be allocated to the community-based organization $(\mathrm{COB})$.

Contribution to Conservation: As per the MoU, FD is supposed to receive 40 per cent of the total revenue. On the other hand, ecotourism would lead to increased collaboration between the FD and communities, thereby to increase the effectiveness of forest governance.

Education Services to Tourists: The tourist guides provides their service to only local tourists who stay in the FD lodge. The focus group discussions and key informant interviews revealed that the visitors are provided with a basic description about the forest in local language, which does not meet the expectations of an ecotourist. Foreign travelers are often accompanied by guides / interpreters from outside. The village tourist guides do not have the capability to serve foreigners due to lack of skills in interpretation and language. As per the gathered information, the ecotourism project in Ilukkumbura carries strengths and weaknesses, as identified below. 
Strengths

- The KNWH with a unique natural advantage has been known as a nature tourism attraction in Sri Lanka.

- The villagers have a positive attitude towards ecotourism.

- The community is organized into the CBO (Dumbara Surakinno), with the primary objective of protecting the KNWH.

\section{Weaknesses}

- The community does not have sufficient understanding and required skills on carrying out a successful ecotourism business.

- Sufficient quality accommodation facilities are not available nearby, except the lodge maintained by the FD.

- The guides are not fluent in English. This could be a barrier in providing interpretation services for the foreign tourists.

- The FD has a focused role of protection and conservation of forests. The FD is not technically equipped to support ecotourism activities.

\section{Private Sector Ecotourism Projects}

There has been an increasing interest in the private sector to carry out ecotourism businesses, since it has become a fast growing market segment, globally. A certain number of private entrepreneurs, who have previous experience in mass tourism or nature tourism, have entered into ecotourism business. The present case study is based on interviews and discussions held with three private nature tourism operators, ecotourism operators and community members.

Community Benefits: As per the available evidence, the relationship between the private ecotourism businesses and local communities in carrying out ecotourism is not mutually beneficial in most of the cases. Community participation, in such businesses, has been limited for unskilled employment, only during certain months of the year. However, there is evidence that certain businesses have managed to get the community involved at all stages and operations of the business, so that both the parties are benefited.

Contribution to Conservation: Conflicts are reported of certain instances between the private tourism operators and state resource managing agencies in carrying out forest-based ecotourism, due to lack of understanding. However, the private sector ecotourism operators in certain instances have contributed to improve environmental conditions in some locations.

Education Services: In terms of provision of environmental education and awareness, few private ecotourism businesses are viewed as successful. Some of the businesses have employed graduates with Science backgrounds as interpreters to educate the tourists, which is a favorable sign. For some of other ecotourism 
businesses, provision of satisfactory interpretation services has not received prime attention.

Strengths

- In most of the cases, owners of the private ecotourism businesses have links to tourism networks, both at national and international level. .

- Given the experience in mass or nature tourism, the private operators have more access to financial institutions, such as banks.

\section{Weaknesses}

- Due to lack of awareness and understanding often communities tend to resist initiation of ecotourism businesses in their localities.

On the other hand, there has been a tendency that tourism operators, who do not offer genuine ecotourism products to use the word 'ecotourism' for their activity. Evidence is available on instances where such businesses have been unsuccessful in the long term, due to the inability of maintain consumer trust. Besides, such activities lead to undermine the image of the Sri Lanka ecotourism sector internationally. Even nature tourism operators using the notion of ecotourism are problematic, since demand for ecotourism cannot be met with general nature tourism products.

\section{Problems and Challenges in Forest-based Ecotourism in Sri Lanka}

An important impediment has been a lack of awareness and understanding on true principles of ecotourism among the stakeholders, as revealed through the stakeholder interviews. As a result, in most of the cases, the term 'ecotourism' is used as a synonym for 'nature tourism'. This has implications on the design and development of true ecotourism products.

The resource base - natural forests required for forest-based ecotourism in Sri Lanka is primarily owned and managed by the state. Carrying out ecotourism as a business is an activity outside the scope and mandate of both the FD and the DWLC. Moreover, the state agencies do not have the required capital and skills in carrying out ecotourism business. Private sector possesses the lead in terms of skills, investment capacity, linkages with tourism networks, etc. However, there has been lack of coordination between other stakeholders of ecotourism as well. The agencies of both sectors operate within their boundaries, without making a coordinated effort in ecotourism development.

Instances are reported that some private ecotourism operators use the 'ecotourism' label, without complying with true ecotourism principles in practice. With the aim of reaping benefits of this emerging market segment, conventional mass tourism or nature tourism products are offered under the label of ecotourism. Sustainability of such false businesses is unlikely to continue in the long run, and incidences are 
reported of failures of such businesses. Such incidences affect negatively on the country's image as a future ecotourism destination. At present, there are no guidelines, standards or certification mechanisms developed for ecotourism products and ecolodges in Sri Lanka.

Community empowerment is one of the main goals of ecotourism. Minimum or no community involvement can be seen in some privately run ecotourism operations. Community members are often hired for low-skilled jobs, only during certain months of the year. Communities are not adequately recognized as a stakeholder by the state forest managing agencies, which would definitely have implications on developing forest-based ecotourism. Besides, lack of recognition of communities as a partner in privately-run ecotourism businesses has led to community resistances in commencing ecotourism projects in some locations.

Attracting genuine eco-tourists is a challenge. Ecotourism, especially when it is based on forests, minimal disturbance to the natural environment and socio-cultural setup should be maintained. In this regard, it is important to attract the nature-loving and conservation-oriented tourists. Interpretation services provided by most of ecotourism operations do not meet the expectations of the tourists in most of the cases. As shown by Walathwewa and Ilukkumbura case studies, the community members are not trained in this regard and have language barriers. Even with the private ecotourism operations, lack of professional interpreters remains a problem in meeting the expectations of ecotourists. Poor interpretation services undermine the ability of ecotourism to generate a good understanding about the attraction and to create a conservation attitude among the tourists.

\section{Policy Implications and Recommendations}

Establishing a well-coordinated mechanism among the tourist agencies and environment agencies should receive high policy priority. At higher level, the MENR and the MoT should have a close coordination with regard to ecotourism. This could be facilitated through an inter-ministerial committee to identify the existing conflicts among tourism policies and initiatives with environment policies.

Assignment of clear roles for relevant stakeholders should be considered essential. Accordingly the MENR, MoT and the agencies coming under the two ministries can play the roles of formulation of required rules and guidelines, setting required standards, effective law enforcement, monitoring and facilitation. The private sector will have to play an important role in managing the businesses as entrepreneurs. The NGOs can play the role of assisting local communities and facilitating achievements of community benefit. Role of provincial councils are also important in allocating resources effectively for the development of ecotourism at local level. The local communities do also have a role in actively participating in ecotourism activities at all stages of the business, so that they gain the expected benefits.

A comprehensive policy and legal framework in place is a prerequisite for development of ecotourism. First, it is important to have a common vision at 
national level for ecotourism, both by environment and tourism sectors. Implementation of draft policy should receive priority in this regard. Also, the policy has to be supported with required legislations, highlighting the required rules and regulations.

Revisions should be made in the FO and Flora and Fauna Protection Ordinance to enable investing tourism income in forest conservation. Private sector involvement in ecotourism should be encouraged. Private sector involvement in ecotourism is crucial since they possess the capacity and skills required for ecotourism. This can be successfully achieved through public-private partnerships. Absence of clear standards and guidelines is viewed to be a major cause for most of the issues faced on ecotourism in Sri Lanka. It is important to establish clear standards and guidelines in offering ecotourism products as well as in carrying out eco-lodges. Simultaneously, this will have to be coupled with a ecotourism certification program to ensure that ecotourism businesses adhere to true ecotourism principles and to make sure that true ecotourism products and services are offered.

\section{References}

Hamele, H. (2004). Ecotrans, Germany, 2004, cited in the International Ecotourism Society (TIES) (2006), Fact Sheet: Global Ecotourism, www.ecotourism.org.

Lindberg, K., B. Furze, M. Staff and R. Black (1997). Ecotourism and Other Services Derived From Forests in the Asia-Pacific Region: Outlook to 2010, Asia-Pacific Forestry Sector Outlook Study Working Paper Series, FAO.

Ministry of Environment and Natural Resources (2003). Caring for the Environment 2003 2007 - Path to Sustainable Development, Colombo, Sri Lanka.

Sri Lanka Tourism Development Authority (SLTDA) (2011). Annual Statistical Report 2011.

Steele, P., N. Sivakumar, H. M. B. C. Herath (1998). A Strategy for Nature Tourism Management in Sri Lanka, Institute of Policy Studies, Colombo.

Tao, C., P. F. J. Eagles, S. L. J. Smith (2004). "Implications of Alternative Definitions of Ecotourists" Tourism Analysis, 9: 1-13.

Tisdell, C. (2003). "Economic Aspects of Ecotourism: Wildlife-based Tourism and Its Contribution to Nature" Sri Lankan Journal of Agricultural Economics, 5(1).

Ratnayake, P. U. (2007). Challenges to Ecotourism Development in Sri Lanka: An Assessment, A thesis submitted in partial fulfillment of the requirements for the Degree of Master of Business Administration in Hospitality and Tourism Management, Prince of Songkla University, Thailand.

Wickramasinge, K, P. Steele and A. Senaratne (2008). Socio-economic Impacts of Forest Conservation on Peripheral Communities: Case of Knuckles National Wilderness Heritage of Sri Lanka, A paper presented at Governing Shared Resources: Connecting Local Experience to Global Challenges, $12^{\text {th }}$ Biennial Conference of the 
International Association for the Study of Commons, Cheltenham England, July 1418, 2008 (http://dlc.dlib.indiana.edu/).

Wight, P. A. (1993). "Sustainable Ecotourism: Balancing Economic, Environmental and Social Goals with Ethical Framework" Journal of Tourism Studies, 4(2).

Wunder, S. (1999). Promoting Forest Conservation Through Ecotourism Income? A Case Study from the Ecuadorian Amazon Region, Occasional Paper No. 21, Center for International Forestry Research.

Yong, U. T. K. (1995). Ecotourism Alternatives in China, Income Generation through Community Forestry, Proceeding of an International Seminar, Bangkok, Thailand. 